\title{
Signet ring cell carcinoma's myelophthisis
}

\author{
Nuno Cercas Pinheiro, ${ }^{1}$ José Rodrigues, ${ }^{2}$ João Pereira, ${ }^{1}$ Alberto Melloe Silva ${ }^{1}$
}

${ }^{1}$ Department of Medicina I, Hospital Egas Moniz, Lisboa, Portugal

${ }^{2}$ Department of Gastrenterology, Hospital Egas Moniz, Lisboa, Portugal

\section{Correspondence to} Dr Nuno Cercas Pinheiro, ncercaspinheiro@gmail.com

Accepted 16 January 2014
CrossMark

To cite: Pinheiro NC, Rodrigues J, Pereira J, et al. BMJ Case Rep Published online: [please include Day Month Year] doi:10.1136/ bcr-2014-203662

\section{DESCRIPTION}

The authors illustrate the case report of a previously healthy, 50-year-old man with severe anaemia and thrombocytopenia, refractory to transfusional support, who was admitted in their hospital for the diagnostic investigation of multiple osteoblastic lesions in the lumbar vertebrae. Along with other complementary diagnostic examinations, upper endoscopy was performed identifying a gastric ulcer at the cardia level. Histopathology revealed a poor differentiated metastatic carcinoma with signet ring cells. Furthermore, the presence of schizocytes in the peripheral blood smear led to the diagnostic hypothesis of cancer-related microangiopathic haemolytic anaemia. The bone marrow biopsy highlighted the presence of gastric carcinoma signet ring cells in medullary stroma, accounting for the severity and persistence of blood cytopenias (figure 1). Despite treatment with plasmapheresis, since there were no clinical conditions to start chemotherapy, the patient died 42 days after diagnosis.

Myelophthisis is the term used for describing the medullary invasion by foreign elements (eg, infection, neoplasm), with functional impairment and ultimately leading to total bone marrow aplasia. Gastric carcinoma invading medullary tissue, particularly the signet ring cell type, is a rare event and is frequently associated with poor prognosis. ${ }^{1}$ It can be associated with severe microangiopathic haemolytic anaemia with a complex and multifactorial physiopathological mechanism that is not yet fully understood. ${ }^{12}$

The only effective treatment seems to be chemotherapy, although in some anecdotical cases, plasmapheresis has been used. ${ }^{1}{ }^{2}$ However, despite treatment, survival does not usually exceed 2 months after the diagnosis has been made. ${ }^{12}$

\section{Learning points}

- Despite its rarity, medullar invasion with refractory cytopenias can be the inaugural manifestation of gastric carcinoma with signet ring cells.

- Bone marrow histopathology presents key features such as areas of carcinoma cells in the stroma and vascular embolisation.

- Chemotherapy seems to be the only effective treatment, but prognosis in the majority of cases, despite treatment, is poor. 
Acknowledgements The authors thank Dr Lucilia Monteiro for the indispensable contribution to this article.

Competing interests None.

Patient consent Obtained.

Provenance and peer review Not commissioned; externally peer reviewed.

\section{REFERENCES}

1 Shin SY, Park H, Chae SW, et al. Microangiopathic hemolytic anemia as the first manifestation of metastatic signet ring cell carcinoma of unknown origin: a case report and review of literature. Korean I Lab Med 2011;31:157-61.

2 Lechner K, Obermeier HL. Cancer-related microangiopathic hemolytic anemia: clinical and laboratory features in 168 reported cases. Medicine (Baltimore) 2012;91:195-205.

Copyright 2014 BMJ Publishing Group. All rights reserved. For permission to reuse any of this content visit http://group.bmj.com/group/rights-licensing/permissions.

BMJ Case Report Fellows may re-use this article for personal use and teaching without any further permission.

Become a Fellow of BMJ Case Reports today and you can:

- Submit as many cases as you like

- Enjoy fast sympathetic peer review and rapid publication of accepted articles

- Access all the published articles

- Re-use any of the published material for personal use and teaching without further permission

For information on Institutional Fellowships contact consortiasales@bmjgroup.com

Visit casereports.bmj.com for more articles like this and to become a Fellow 